Dear Author,

Please, note that changes made to the HTML content will be added to the article before publication, but are not reflected in this PDF.

Note also that this file should not be used for submitting corrections. 


\title{
Marine litter on Mediterranean shores: Analysis of composition, spatial distribution and sources in north-western Adriatic beaches
}

\author{
Cristina Munari ${ }^{\mathrm{a}}$, Corinne Corbau ${ }^{\mathrm{b}}$, Umberto Simeoni ${ }^{\mathrm{b}}$, Michele Mistri ${ }^{\mathrm{a}, *}$ \\ a Department of Life Sciences and Biotechnologies, University of Ferrara, Via L. Borsari 46, 44121 Ferrara, Italy \\ ${ }^{\mathrm{b}}$ Department of Physics and Earth Sciences, University of Ferrara, Via G. Saragat 1, 44122 Ferrara, Italy
}

\section{A R T I C L E I N F O}

\section{Article history:}

Received 18 August 2015

Revised 14 December 2015

Accepted 14 December 2015

Available online $\mathrm{xxxx}$

\section{Keywords:}

Marine litter

Marine Strategy Framework Directive

In situ deposition

Adriatic Sea

\begin{abstract}
A B S T R A C T
Marine litter is one descriptor in the EU Marine Strategy Framework Directive (MSFD). This study provides the first account of an MSFD indicator (Trends in the amount of litter deposited on coastlines) for the north-western Adriatic. Five beaches were sampled in 2015. Plastic dominated in terms of abundance, followed by paper and other groups. The average density was 0.2 litter items $\mathrm{m}^{-2}$, but at one beach it raised to 0.57 items $\mathrm{m}^{-2}$. The major categories were cigarette butts, unrecognizable plastic pieces, bottle caps, and others. The majority of marine litter came from land-based sources: shoreline and recreational activities, smoke-related activities and dumping. Sea-based sources contributed for less. The abundance and distribution of litter seemed to be particularly influenced by beach users, reflecting inadequate disposal practices. The solution to these problems involves implementation and enforcement of local educational and management policies.
\end{abstract}

(C) 2015 Published by Elsevier Ltd.

\section{Introduction}

The Marine Strategy Framework Directive, MSFD (2008/56/EC; European Commission, 2008) establishes a framework for each Member State to take action to achieve or maintain Good Environmental Status (GES) for the marine environment by 2020. The MSFD follows a holistic functional approach identifying a set of 11 Descriptors, which collectively represent the state and functioning of the whole system (Borja et al., 2010). Descriptor 10 (D10) is identified as "Properties and quantities of marine litter do not cause harm to the coastal and marine environment" (European Commission, 2008). Marine litter is any persistent, manufactured or processed solid material discarded, disposed of or abandoned in the marine and coastal environment; it consists of items that have been made or used by people and deliberately discarded or unintentionally lost into the sea or coastline including such materials transported into the marine environment (UNEP, 2009). Marine litter can be broadly categorized according to its source into land (land-borne sources) and marine-based (sea-borne sources) items: the former mainly originates from domestic, agricultural and industrial activities, while the latter originates from fisheries, recreational boats, and shipping (UNEP, 2009). UNEP (2009) estimated that approximately 6.4 million tonnes of litter are dumped

\footnotetext{
* Corresponding author.

E-mail address: msm@unife.it (M. Mistri).
}

in the oceans each year. So, marine litter accumulation and dispersal is a growing problem at a global scale, affecting all marine environments (Gregory, 2009).

According to its weight and shape, marine litter can be divided into two categories: floating litter and sinking litter. Sandy shores are important sinks for floating litter, which after stranding generally becomes trapped in/under sand or might be blown farther inland (Kusui and Noda, 2003; Jayasiri et al., 2013). Litter stranded on the coastline is a serious affront to the visual and other aesthetic sensitivities of tourists and local visitors to beaches, as it curtails beach enjoyment: destinations where no beach cleanup is regularly conducted acquire a bad reputation and are avoided by tourists, with important consequences on the local economy. As a matter of fact, one indicator (10.1.1) for D10 in MSFD is "Trends in the amount of litter washed ashore and/or deposited on coastlines, including analysis of its composition, spatial distribution and, where possible, source" (Commission Decision 2010/477/EU). Surveys of litter stranded on the coastline are a primary tool for monitoring the load of litter in the marine environment and have been used to describe marine litter pollution. They can be used to measure the effectiveness of management or mitigation measures, the sources and activities leading to litter pollution and threats to marine biota and ecosystems (Cheshire et al., 2009).

Even though marine litter is a worldwide problem, it has been little studied in the Mediterranean area (PNUE/PAM/MEDPOL, 2009), and particularly in Italy. Surfing WoS, Scopus and Google 
thereby facilitating the search for solutions. The ultimate goal is to provide insights into possible approaches to manage marine litter deposition. Selected beaches do not host lidos because they are included into the two Regional Parks of the Po Delta (Veneto and Emilia Romagna), and are part of the system of the protected areas within the Natura 2000 Italian network. The study focused principally on the following questions: (i) what is the quantity, composition and distribution of marine litter in north-western Adriatic beaches, (ii) are there differences in the types of litter at different locations, and finally (iii) which are the sources of litter. We also assessed the cleanliness of selected beaches using an appropriate indicator. The ultimate purpose of this study was to provide the first assessment of marine litter (MSFD indicator 10.1.1) at the beaches in the Po Delta area.

\section{Methods}

\subsection{Study area}

fishing and recreational maritime activities. In lidos, beach cleanup is made daily by lido's personnel; in free access beaches, beach cleanup is made occasionally by volunteers. Although northwestern Adriatic coast is vast and of huge commercial importance, no studies have made a space inventory litter survey of beaches.

Taking into account the very scarce information available on marine litter, and that the marine litter is one of the descriptors of the MSFD, with the present study we wanted to assess, for the first time in the north-western Adriatic coast, the quality and quantity of marine litter occurring in selected free access beaches to address the gap in knowledge and to serve as a baseline for future comparisons. Knowledge of the abundances and types of stranded marine litter is important to identify possible sources,

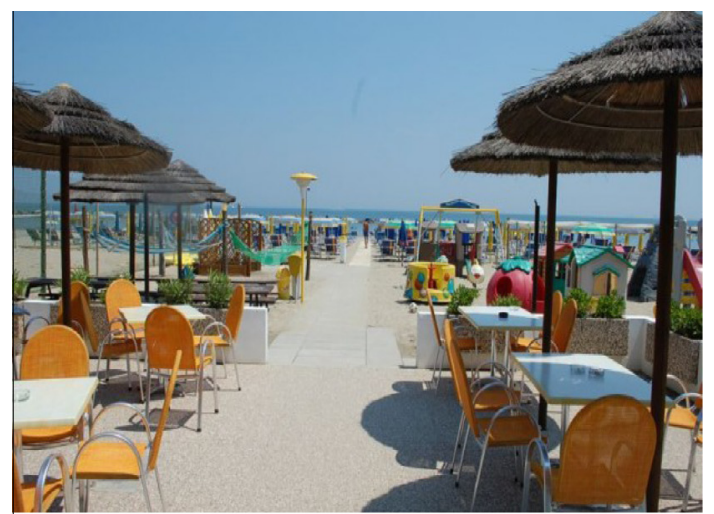

(a)

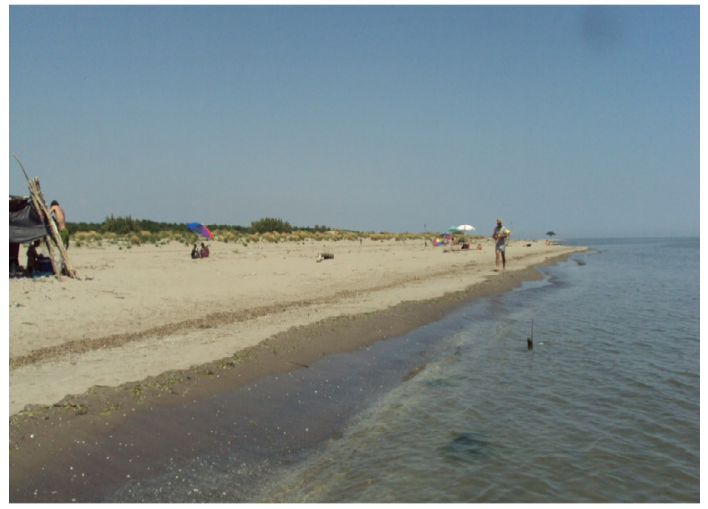

(b)

Fig. 1. (a) A beach structured as a "lido"; (b) a free access beach.
Along the north-western Adriatic coast a large number of rivers discharge into the sea, being the Po River the most relevant, followed by the Adige. The area is subjected to intense marine traffic from supplier vessels for offshore activities (gas platforms), trawlfishing vessels, and recreational boats. It is also an area of intense aquaculture, with offshore mussel farms, and coastal clam cultivations. Beaches vary in breadth from a few meters to over $200 \mathrm{~m}$. Five free access beaches, included in the Po River Delta Parks and in the Natura 2000 Italian network, were chosen (Fig. 2): Rosolina (IT3270004) in the Veneto Regional Park, Volano (IT4060007), Bellocchio (IT4060003), Casalborsetti (IT4070005), and Bevano (IT4070009) in the Emilia Romagna Regional Park. Beach characteristics are summarized in Table 1.

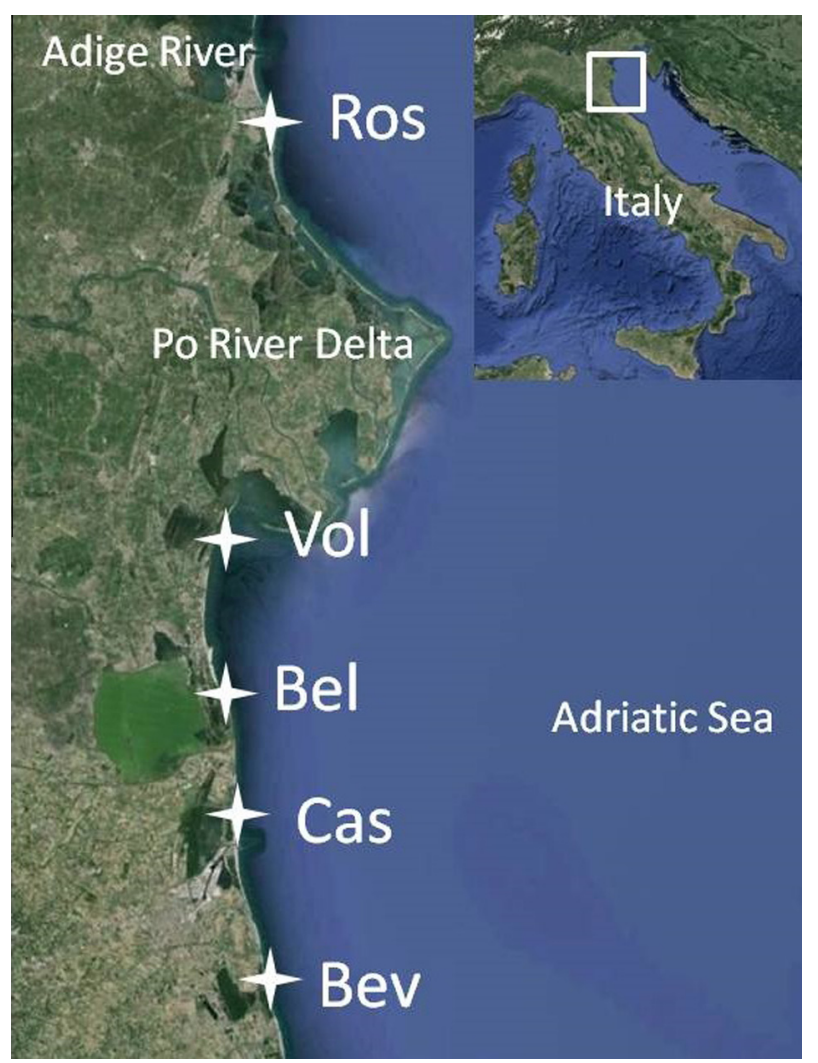

Fig. 2. Location of the study beaches (Ros: Rosolina; Vol: Volano; Bel: Bellocchio; Cas: Casalborsetti; Bev: Bevano). 
Table 1

Characteristics of considered beaches.

\begin{tabular}{|c|c|c|c|c|c|c|}
\hline & $\begin{array}{l}\text { Total beach length } \\
\mathrm{km}\end{array}$ & $\begin{array}{l}\text { Unanthropized beach length } \\
\mathrm{km}\end{array}$ & $\begin{array}{l}\text { Beach width } \\
\mathrm{m}\end{array}$ & Beach slope & $\begin{array}{l}\text { Sediment diameter } \\
\varphi\end{array}$ & $\begin{array}{l}\text { Distance from parking areas } \\
\mathrm{km}\end{array}$ \\
\hline Rosolina & 8 & 3 & $20-210$ & $0.5-3$ & $2-2.5$ & 0.75 \\
\hline Volano & 4.5 & 2.5 & $10-70$ & 0.5 & $2-2.5$ & 0.12 \\
\hline Bellocchio & 3.5 & 3.5 & $10-60$ & 1 & 2 & 0.65 \\
\hline Casalborsetti & 3 & 2 & $5-80$ & $2-3$ & 2.5 & 0.4 \\
\hline Bevano & 6 & 4.5 & $10-60$ & 2.5 & 2.5 & 1 \\
\hline
\end{tabular}

\subsection{Sampling and analysis}

Beach surveys were conducted at the 5 beaches from May to June 2015. The cleaning of these beaches, promoted by local NGOs like Legambiente or WWF, is occasional (grossly once a year) and carried out by citizens and school groups on a voluntary basis. The study beaches had not been cleaned for at least six months.

Sampling was performed according to the operational guidelines for rapid beach litter assessment described by Cheshire et al. (2009). Two 50-m transects were randomly placed along each beach parallel to the shoreline, and all litter greater than $2 \mathrm{~cm}$ was collected in the area ranging from the water edge to the back of the beach (determined by the presence of vegetation) within the 50-m transect. In order to determine the area searched, the width of the beach was assessed at the mid-point of each transect by means of a Leica Geovid $7 \times 42$ BDA rangefinder binocular. The average beach width was measured as $30 \mathrm{~m}$ at Rosolina and Bellocchio, and $20 \mathrm{~m}$ at Volano, Casalborsetti and Bevano. The survey are therefore ranged between $3000 \mathrm{~m}^{2}$ (Rosolina and Bellocchio) and $2000 \mathrm{~m}^{2}$ (the other beaches). Litter stranded was classified in relation to 77 categories and 9 major groups (plastic, foamed plastic, cloth, glass and ceramic, metal, paper and cardboard, rubber, wood, other) indicated by Cheshire et al. (2009).

The sources of marine litter were classified into five major categories including: (i) shoreline and recreational activities (e.g. bottles, caps, toys, etc.), (ii) smoking-related activities (e.g. lighters, cigarette butts, etc.), (iii) boat/fishing/farming activities (e.g. buoys, nets, fishing lines, etc.), (iv) dumping activities (e.g. building materials, tires, etc.), and (v) medical/personal hygiene (e.g. syringes, tampons, etc.) (Ocean Conservancy, 2010). The relationship between the amount of litter on each beach and the distance from the nearest parking area was investigated through regression analysis.

Beach cleanliness was assessed through Alkalay et al.'s (2007) Clean Coast Index (CCI):CCI = (Total litter on transect $/$ Total area of transect) $\times$ Kwhere the CCI is the number of litter $\mathrm{m}^{-2}$, the total area of transect is the product of the transect length and width, and $K$ (constant) $=20$. Beaches were classified from "Clean" to "Extremely dirty" according to the scale provided by Alkalay et al. (2007) and shown in Table 2.

The heterogeneity of marine litter at each beach was calculated through the Shannon-Wiener's diversity index $\left(\mathrm{H}^{\prime}\right)$, and the Pielou's evennes index $\left(\mathrm{J}^{\prime}\right)$. These are quantitative measures that reflect how many different types there are in a dataset, and simultaneously takes into account how evenly the basic entities are distributed among those types.

Table 2

Clean Coastal Index: value and definition for each quality class (from Alkalay et al., 2007).

\begin{tabular}{lll}
\hline Quality & Value & Definition \\
\hline Very clean & $0-2$ & No litter is seen \\
Clean & $2-5$ & No litter is seen over a large area \\
Moderate & $5-10$ & A few pieces of litter can be detected \\
Dirty & $10-20$ & A lot of litter on the shore \\
Very dirty & $20+$ & Most of the beach is covered with litter \\
\hline
\end{tabular}

Marine litter composition at the 5 beaches was investigated by means of classification-clustering based on the Bray-Curtis similarity index and UPGMA sorting of untransformed quantity data. The litter categories contributing to dissimilarity between beaches were investigated using the similarity percentages (SIMPER) analysis (Clarke, 1993).

Differences in litter composition and quantity between beaches were analyzed through PERMANOVA (Anderson et al., 2008) according to a one-way experimental design. For the oneway case, an exact $P$-value was provided using unrestricted permutation of raw data. When low unique values in the permutation distribution were available, asymptotical Monte Carlo $P$-values were used instead of permutational $P$-values. All the analyses were performed using PRIMER 6 and PERMANOVA+ (Anderson et al., 2008).

\section{Results}

The surveys at the 5 beaches recorded a total of 2502 marine litter items. Items ranged in size from large buoys ripped off from offshore mussel farms, to small fragments of plastic. The number of

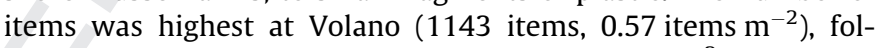
lowed by Bellocchio (391 items, 0.13 items $\mathrm{m}^{-2}$ ), Rosolina ( 371 items, 0.12 items $\mathrm{m}^{-2}$ ), Bevano (315 items, 0.16 items $\mathrm{m}^{-2}$ ), and Casalborsetti (282 items, 0.14 items $\mathrm{m}^{-2}$ ). Marine litter was classified into 35 categories and eight major groups (Table 3 ). The greater majority $(81.1 \%)$ was made of plastic, a category of litter dominant in beaches all over the world. Paper and cardboard was the second most abundant group at beaches (7\%), followed by glass and ceramics (3.9\%), foamed plastic (3.3\%), rubber $(1.4 \%)$ and wood (1.2\%). Among the 35 litter categories, cigarette butts accounted for the highest percentage (22.9\%), followed by unrecognizable plastic pieces (13.5\%), bottle caps (9.2\%), mesh bags (7.2\%), plastic bottles and cutlery (6.5\% and 6.4\%, respectively). The highest load on a single transect was at Volano, where we found 578 items in one transect, mostly comprising plastic.

Cigarette butts dominated the plastic group at all the 5 beaches, in Bevano and Volano representing 35.4\% and 30\% of total plastic items, respectively (Table 3 ). The largest number of cigarette butts (287 items) was recovered from Volano, equalling a density of 0.14 filters $\mathrm{m}^{-2}$. Density of unrecognizable pieces was higher at Volano $\left(0.08\right.$ pieces $\left.\mathrm{m}^{-2}\right)$, followed by Rosolina $\left(0.03\right.$ pieces $\left.\mathrm{m}^{-2}\right)$, and Bellocchio $\left(0.02\right.$ pieces $\mathrm{m}^{-2}$ ). Mesh bag density (mainly mussel bags) was higher in Volano ( 0.057 items $\mathrm{m}^{-2}$ ), while other beaches had much lower densities $\left(<0.001\right.$ items $\left.\mathrm{m}^{-2}\right)$.

Marine litter sources (Fig. 3) were primarily shoreline and recreational activities (948 items, 37.9\%), followed by products of smoke-related activities (638 items, 25.5\%), dumping (474 items, 18.9\%; unrecognizable plastic pieces were put in this category), and boat/fishing/farming activities (421 items, 16.8\%). Very few health/medical supplies were found in the marine litter, amounting to only 21 items, which accounted for $0.8 \%$.

The Clean Coast Index classified Volano as a "Dirty" beach $(\mathrm{CCI}=11.4)$. The other beaches ranked as "Clean": Rosolina, $\mathrm{CCI}=2.5$; Bellocchio, $\mathrm{CCI}=2.6$; Casalborsetti, $\mathrm{CCI}=2.8$; Bevano, $\mathrm{CCI}=3.2$. 
Table 3

Amount of litter in the 5 beaches. Empty spaces represent zero items.

\begin{tabular}{|c|c|c|c|c|c|}
\hline & Rosolina & Volano & Bellocchio & Casalborsetti & Bevano \\
\hline \multicolumn{6}{|l|}{ Plastic } \\
\hline Bottle caps & 41 & 85 & 58 & 18 & 28 \\
\hline Bottles & 25 & 86 & 21 & 12 & 18 \\
\hline Cutlery & 16 & 45 & 39 & 32 & 29 \\
\hline Food containers & 15 & 32 & 12 & 15 & 9 \\
\hline Plastic bags & 18 & 62 & 15 & 11 & 15 \\
\hline Toys & 4 & 15 & & 4 & 5 \\
\hline Gloves & & 7 & & 2 & \\
\hline Cigarette lighters & 2 & 15 & & 4 & 5 \\
\hline Cigarettes butts & 79 & 287 & 61 & 58 & 87 \\
\hline Syringes & 1 & & & & \\
\hline Crates & & 11 & 3 & & \\
\hline Mesh bags & 8 & 114 & 31 & 15 & 12 \\
\hline Fishing gears & 6 & 5 & 3 & 2 & 2 \\
\hline Monofilament line & 10 & 25 & 15 & 7 & 6 \\
\hline Rope & 2 & & 2 & 3 & \\
\hline Fishing net & 3 & 7 & 3 & & \\
\hline Buoys & & 3 & & & 1 \\
\hline Unrecognizable pieces & 58 & 159 & 55 & 37 & 29 \\
\hline \multicolumn{6}{|l|}{ Foamed plastic } \\
\hline Packaging (pieces) & 8 & 38 & 12 & 9 & 15 \\
\hline \multicolumn{6}{|l|}{ Cloth } \\
\hline Clothing, shoes, etc. & 4 & 11 & 2 & & 2 \\
\hline \multicolumn{6}{|l|}{ Glass and ceramic } \\
\hline Light globes/bulbs & & 3 & 2 & 1 & \\
\hline Glass fragments & 22 & 39 & 12 & 9 & 10 \\
\hline \multicolumn{6}{|l|}{ Metal } \\
\hline Drink cans & 3 & & 3 & 8 & 5 \\
\hline Gas bottles & & 1 & & & \\
\hline \multicolumn{6}{|l|}{ Paper and cardboard } \\
\hline Paper & 26 & 45 & 25 & 9 & 10 \\
\hline Boxes and fragments & 2 & 6 & & 11 & \\
\hline Cigarette packs & 4 & 15 & 5 & 7 & 9 \\
\hline \multicolumn{6}{|l|}{ Rubber } \\
\hline Toys & & & 6 & 2 & 5 \\
\hline Flip-flops & 2 & 1 & & 2 & \\
\hline Gloves & 2 & 6 & & & 1 \\
\hline Rubber sheets & & 3 & & & \\
\hline Condoms & 1 & & & & 3 \\
\hline \multicolumn{6}{|l|}{ Wood } \\
\hline Corks & 2 & 3 & 4 & 2 & 8 \\
\hline Ice-cram sticks & 3 & 5 & 2 & & \\
\hline \multicolumn{6}{|l|}{ Other } \\
\hline Sanitary & 4 & 9 & & 2 & 1 \\
\hline
\end{tabular}

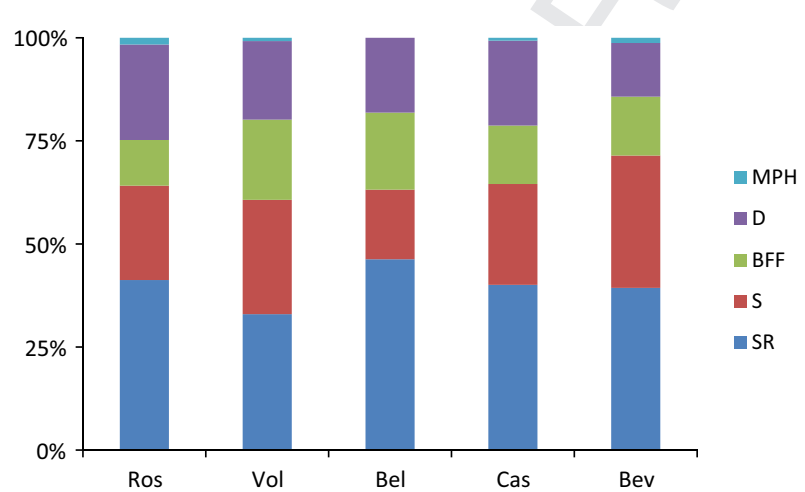

Fig. 3. Sources of marine litter (SR: shoreline and recreational activities; S: smoking-related activities; BFF: boat/fishing/farming activities; D: dumping activities; MPH: medical/personal hygiene) at the five beaches.

In Fig. 4 the heterogeneity of marine litter at each beach is shown. Litter diversity ranged from $3.9( \pm 0.16 \mathrm{SD})$ at Casalborsetti, to $3.63( \pm 0.26 \mathrm{SD})$ at Bevano. Volano showed the lowest litter equitability ( $0.77 \pm 0.02)$. Classification analysis (Fig. 5) shows that Volano differed from all the other beaches. This result was confirmed by PERMANOVA (Table 4). As the number of unique values under permutations was very low, $P$-values were obtained using Monte Carlo samples from the asymptotic permutation distribution (Anderson and Robinson, 2003). Similarity percentages analysis (SIMPER) was used to identify which types of litter primarily drove the differences between beaches (Table 5). This analysis identified 10 categories that were consistently responsible for a large percentage ( $>50 \%)$ of the overall differences: cigarette butts, mesh bags, bottles, bottle caps, plastic cutlery, plastic bags, unrecognizable pieces of plastic, paper, paper boxes and glass fragments. Volano and Casalborsetti were the most dissimilar beaches regarding litter composition (dissimilarity: 63.7\%), while Casalborsetti and Bevano the most similar (dissimilarity: 28.1\%).

At Rosolina, the nearest car parking area was at about $750 \mathrm{~m}$ from the beach, at Volano at $120 \mathrm{~m}$, at Bellocchio at $650 \mathrm{~m}$, at Casalborsetti at $400 \mathrm{~m}$, and finally at Bevano at $1000 \mathrm{~m}$. A significant inverse relationship (regression ANOVA: $F=9.95$; df $=1,8$; $P=0.013$ ) was found between the distance from the nearest car parking area and the amount of litter (Fig. 6). 

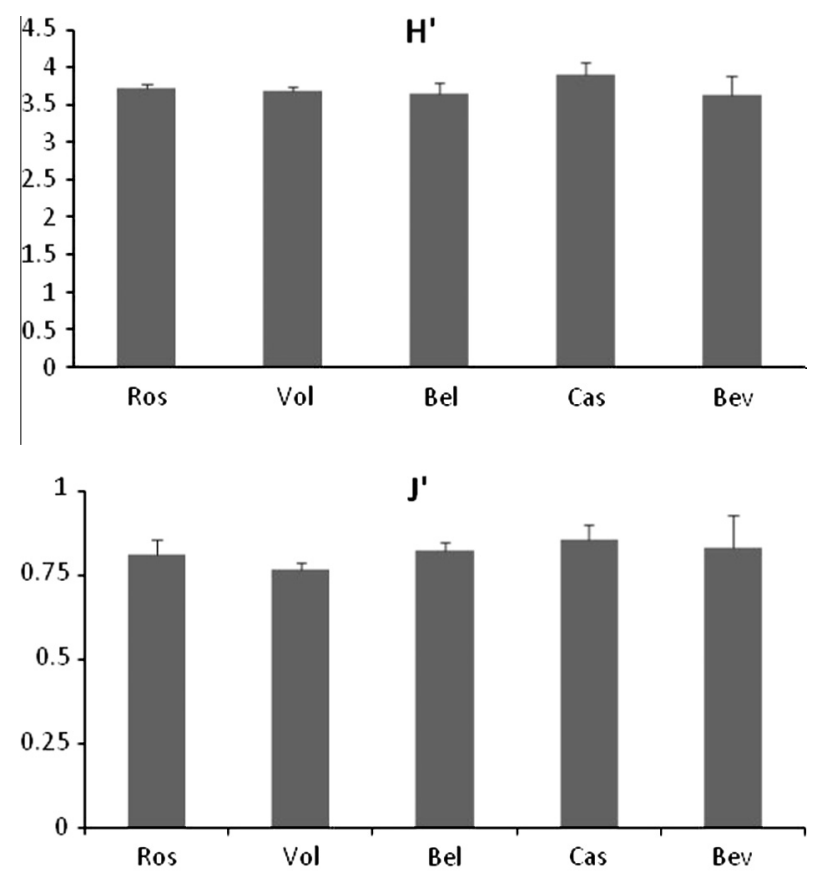

Fig. 4. Diversity $\left(\mathrm{H}^{\prime}\right)$ and evenness $\left(\mathrm{J}^{\prime}\right)$ of marine litter at each beach (abbreviations as in Fig. 1).

\section{Discussion}

\subsection{Beach cleanliness}

Visual descriptions of beach cleanliness provided by Alkalay et al. (2007) were usually consistent with the CCI values obtained. Only Volano scored as "dirty", and in fact a lot of litter was visible on the beach. The other 4 beaches were classified as "clean". To our knowledge, excluding Alkalay's et al. (2007) paper, the index was applied so far only on beaches from Slovenia (Langlbauer et al., 2014). The cleanliness of those beaches resulted unsatisfactory, with 5 out of 6 beaches scoring "extremely dirty/dirty", one "moderate", and none "clean". Langlbauer et al. (2014) identified the tourism sector and outflow of untreated wastewater as the causes of their results. Results from this survey equate to approximately 0.2 litter items $\mathrm{m}^{-2}$. Densities of marine litter on beaches in the
Table 4

Pair-wise tests from PERMANOVA on unrestricted permutation of raw data. Significant $P$-values (MC: Monte Carlo test) are in bold.

\begin{tabular}{lll}
\hline & $t$ & $P(\mathrm{MC})$ \\
\hline Ros vs Vol & 2.743 & $\mathbf{0 . 0 4 7}$ \\
Ros vs Bel & 1.035 & 0.431 \\
Ros vs Cas & 1.578 & 0.173 \\
Ros vs Bev & 1.009 & 0.447 \\
Vol vs Bel & 2.472 & 0.066 \\
Vol vs Cas & 3.787 & $\mathbf{0 . 0 2 6}$ \\
Vol vs Bev & 2.629 & $\mathbf{0 . 0 5 0}$ \\
Bel vs Cas & 1.473 & 0.213 \\
Bel vs Bev & 1.029 & 0.427 \\
Cas vs Bev & 0.914 & 0.514 \\
\hline
\end{tabular}

north-western Adriatic were similar to those reported from Ireland and Pitcairn Island (Benton, 1995), and Russia (Kusui and Noda, 2003), resulting among the lowest litter quantity found in other parts of the world (Table 6). Among the 5 examined beaches, we found that Volano $\left(0.57\right.$ items $\mathrm{m}^{-2}$ ) accumulated significantly more marine litter than the others (range: $0.12-0.16$ items $\mathrm{m}^{-2}$ ). At the 5 beaches the most represented categories of litter were almost the same: cigarette butts, bottles, bottle caps, and unrecognizable pieces of plastic, but the relative amounts differed as shown by different values exhibited by heterogeneity and evenness indices.

\subsection{Beach litter composition}

The vast majority of marine litter collected on all the 5 beaches was plastic, according to the observation that plastic seems to be the most common type of marine litter worldwide (Thompson, 2006). The main reason for this is that plastic is used in almost all human activities (professional and recreational), together with its long persistence in the marine environment (Derraik, 2002). Among plastic, cigarette butts were the most frequently found type of litter, a finding consistent with the results found by Langlbauer et al. (2014) on Slovenian beaches, and by Lopes da Silva (2015) on Brazilian beaches. Other plastic items with the highest occurrence were: small fragments, bottles and bottle caps, cutlery, and mesh bags. Their presence is a good indicator of pollution from beach users. On Tyrrhenian sandy shores, Poeta et al. (2014) found plastic fragments, plastic bottles, bottle caps and plastic drinking glass to be the items with the highest occurrence. Due to the plasticlimitation policy recently implemented by the Italian Government

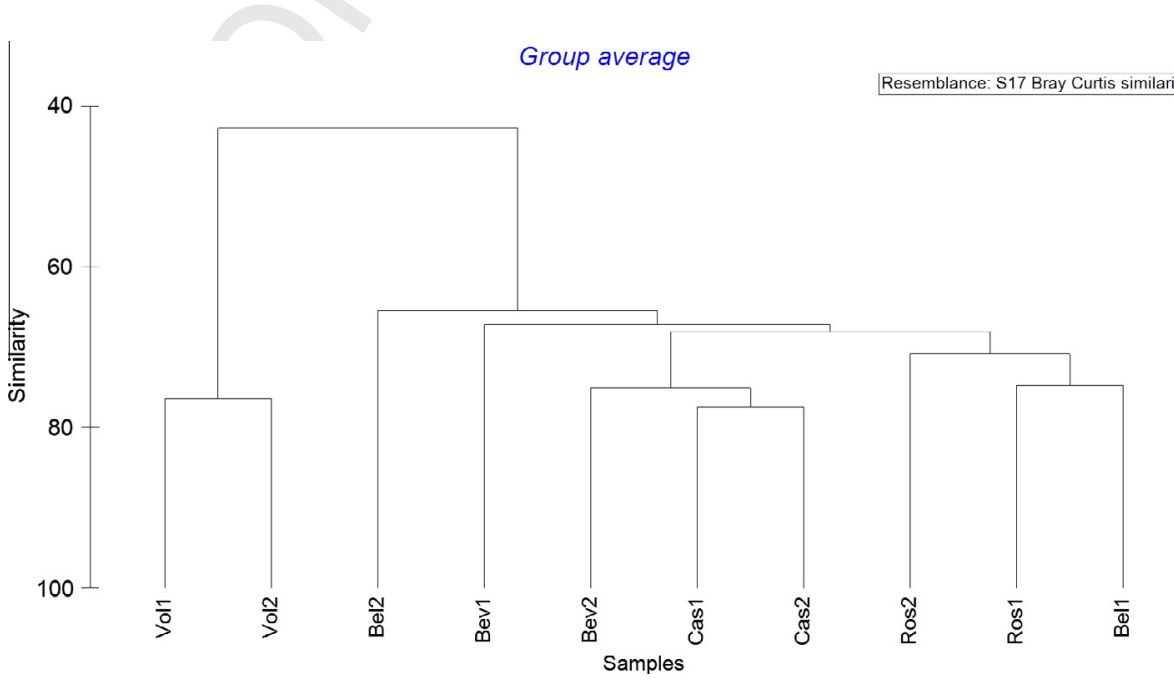

Fig. 5. Classification analysis of the 5 study beaches (abbreviations as in Fig. 1; numbers indicate replicates). 
Table 5

SIMPER analysis.

\begin{tabular}{|c|c|c|c|c|c|c|c|}
\hline \multirow[t]{4}{*}{ Ros vs Vol } & Avg dis $=53.05$ & Contrib\% & Cum.\% & Vol vs Cas & Avg dis $=63.66$ & Contrib\% & Cum.\% \\
\hline & Cigarettes butts & 26.01 & 26.01 & & Cigarettes butts & 25.31 & 25.31 \\
\hline & Mesh bags & 13.22 & 39.24 & & Unrec pieces & 13.44 & 38.75 \\
\hline & Unrec pieces & 12.57 & 51.8 & & Mesh bags & 10.94 & 49.69 \\
\hline \multirow[t]{6}{*}{ Ros vs Bel } & Avg dis $=30.02$ & Contrib\% & Cum.\% & Vol vs Bev & Avg dis $=59.83$ & Contrib\% & Cum.\% \\
\hline & Cigarettes butts & 12.88 & 12.88 & & Cigarettes butts & 22.93 & 22.93 \\
\hline & Unrec pieces & 10.98 & 23.87 & & Unrec pieces & 14.88 & 37.81 \\
\hline & Mesh bags & 9.99 & 33.85 & & Mesh bags & 11.71 & 49.52 \\
\hline & Cutlery & 9.87 & 43.72 & & Bottles & 7.76 & 57.28 \\
\hline & Bottle caps & 9.54 & 53.26 & & & & \\
\hline \multirow[t]{6}{*}{ Ros vs Cas } & Avg dis $=33.19$ & Contrib\% & Cum.\% & Bel vs Cas & Avg dis $=34.16$ & Contrib\% & Cum.\% \\
\hline & Cigarettes butts & 14.77 & 14.77 & & Bottle caps & 17.43 & 17.43 \\
\hline & Bottle caps & 10.13 & 24.9 & & Unrec pieces & 10.69 & 28.13 \\
\hline & Unrec pieces & 9.84 & 34.74 & & Cigarettes butts & 10.08 & 38.21 \\
\hline & Paper & 8.06 & 42.8 & & Mesh bags & 7.06 & 45.27 \\
\hline & Cutlery & 7.24 & 50.04 & & Paper & 7.03 & 52.3 \\
\hline \multirow[t]{7}{*}{ Ros vs Bev } & Avg dis $=31.82$ & Contrib\% & Cum.\% & Bel vs Bev & Avg dis $=33.50$ & Contrib\% & Cum.\% \\
\hline & Unrec pieces & 13.28 & 13.28 & & Cigarettes butts & 15.58 & 15.58 \\
\hline & Cigarettes butts & 12.9 & 26.18 & & Bottle caps & 12.72 & 28.3 \\
\hline & Bottle caps & 8.43 & 34.61 & & Unrec pieces & 12.5 & 40.8 \\
\hline & Paper & 7.51 & 42.13 & & Mesh bags & 8.02 & 48.81 \\
\hline & Cutlery & 5.79 & 47.92 & & Paper & 6.39 & 55.2 \\
\hline & Glass fragments & 5.56 & 53.48 & & & & \\
\hline \multirow[t]{7}{*}{ Vol vs Bel } & Avg dis $=52.35$ & Contrib\% & Cum.\% & Cas vs Bev & Avg dis $=28.13$ & Contrib\% & Cum.\% \\
\hline & & & & & Cigarettes butts & 23.66 & 23.66 \\
\hline & Cigarettes butts & 28.15 & 28.15 & & Unrec pieces & 7.05 & 30.71 \\
\hline & Unrec pieces & 12.96 & 41.11 & & Boxes and fragments & 6.57 & 37.28 \\
\hline & Mesh bags & 10.37 & 51.48 & & Bottles & 5.92 & 43.2 \\
\hline & & & & & Bottle caps & 5.91 & 49.11 \\
\hline & & & & & Plastic bags & 5.22 & 54.32 \\
\hline
\end{tabular}

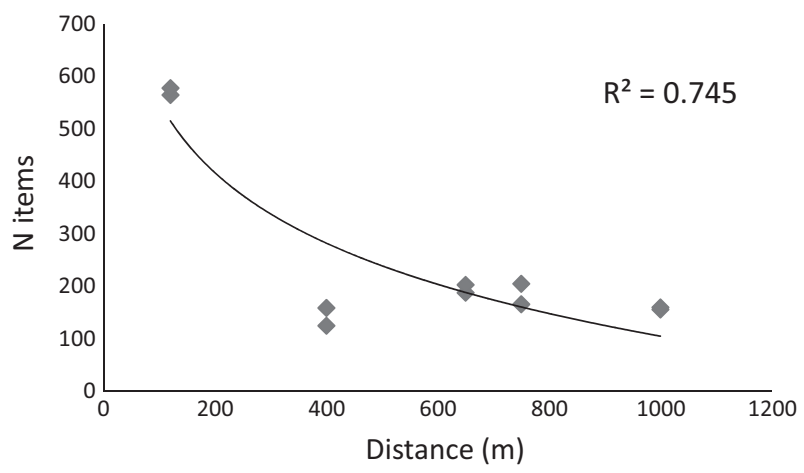

Fig. 6. Relationship between the distance from the nearest car parking area and the amount of litter on beaches.

(National Act D.Lgs.91/2014, issued on June 2014, prohibiting the marketing of non-biodegradable shoppers), the percentage of plastic bags was fairly limited (4.8\%) and similar to other localities, such as Slovenia (Langlbauer et al., 2014), and Taiwan (Liu et al., 2013; Kuo and Huang, 2014). In some studies, other items than plastic (e.g. foamed plastic, or wood) were more common, most likely due to specific sources or local customs. For example, large quantities of foamed plastic are often observed in areas with extensive aquaculture installations (Hinojosa and Thiel, 2009). In our study, foamed plastic was found especially at Volano, a beach in front of which there are shellfish farms.

\subsection{Beach litter source}

Determining the type and source of marine litter on beaches is important to develop actions aimed at minimizing the presence of these in the environment. For the Mediterranean Sea, PNUE/PAM/
MEDPOL (2009) reported that most of the marine litter comes from land-based rather than sea-based sources. According to the analysis of data collected between 2002 and 2006, 52\% of marine litter in the Mediterranean originates from shoreline and recreational activities, $40 \%$ from smoke-related activities, 5\% from boat activities, $2 \%$ from dumping activities, and $1 \%$ from medical and personal hygiene (PNUE/PAM/MEDPOL, 2009). Our results showed that, in north-western Adriatic beaches too, the majority of marine litter comes from land-based sources, but relative percentages were different. In this study the source of marine litter was primarily shoreline and recreational activities, accounting for 37.9\% of litter sources, a value however which is much lower than the global average in 2010 (68.2\%; Ocean Conservancy, 2010), or the Mediterranean average (52\%; PNUE/PAM/MEDPOL, 2009). Smoke-related activities (cigarette butts, lighters, cigarette packs) were the second litter origin, but with a value (25.5\%) much lower than indicated for the Mediterranean (40\%). The high percentages of in situ deposited litter that we found at the 5 study beaches are likely caused by the high number of visitors, more than 700,000 annually (http://statistica.regione.veneto.it; http://imprese.regione.emilia-romagna.it). In free access beaches, like those considered in this study, tourists carry food and recreational equipment that are not properly disposed of, leading to such a high percentage of recreational and smoke-related litter. Volano had the highest density of in situ deposited litter. The likely explanation could be: (i) Volano is the more easily accessible beach, due to the proximity of a car parking area; (ii) a difference in social attitude and behavior of beach users between areas, in that beach users at Volano drop considerably more litter than those in the other beaches. Unfortunately, at present it is scarcely known how attitudes of tourists vary along the 5 considered beaches.

Litter originating from boat activities and fishery/farming behavior contributed substantially (this study: 16.8\%; Mediterranean average: 5\%; PNUE/PAM/MEDPOL, 2009), but did not reach 
Table 6

Densities of marine litter reported from beaches throughout the world.

\begin{tabular}{llll}
\hline Country & $\begin{array}{l}\text { No. surveyed } \\
\text { beaches }\end{array}$ & $\begin{array}{l}\text { Avg density } \\
\left(\text { items }{ }^{-2}\right)\end{array}$ & References \\
\hline Italy & 5 & 0.2 & This study \\
Ireland & 1 & 0.2 & Benton (1995) \\
Scotland & 16 & 0.4 & Velander and Mocogni (1999) \\
Slovenia & 6 & 1.51 & Langlbauer et al. (2014) \\
Russia & 8 & 0.2 & Kusui and Noda (2003) \\
Jordan & 3 & 4 & Abu-Hilal and Al-Najjar (2004) \\
Oman & 11 & 0.4 & Claereboudt (2004) \\
Japan & 18 & 3.4 & Kusui and Noda (2003) \\
South Korea & 6 & 1 & Lee et al. (2013) \\
Taiwan & 6 & 0.15 & Kuo and Huang (2014) \\
Indonesia & 21 & 4.6 & Evans et al. (1995) \\
Australia & 6 & 0.1 & Cunningham and Wilson (2003) \\
Australia & 1 & 0.5 & Foster-Smith et al., 2007 \\
Australia & 1 & 0.24 & Smith and Markic (2013) \\
Pitcairn Island & 2 & 0.2 & Benton (1995) \\
Tasmania & 9 & 0.28 & Slavin et al. (2012) \\
Panama & 19 & 3.6 & Garrity and Levings (1993) \\
Brasil & 2 & 0.7 & Araújo et al. (2006) \\
Brasil & 10 & 0.14 & Oigman-Pszczol and Creed (2007) \\
Brasil & 5 & 4.98 & Widmer and Hennemann (2010) \\
Chile & 43 & 1.8 & Bravo et al. (2009) \\
\hline
\end{tabular}

the high proportions observed in other studies (e.g. Walker et al., 1997). It must be stressed that prohibitions regarding the disposal of litter are particularly strict in the Mediterranean (a Special Area under the MARPOL 73/78 International Convention), given that, since 2009, the disposal into the sea of all plastics, paper products, glass, bottles, packing materials, and all other garbage is forbidden (PNUE/PAM/MEDPOL, 2009). The amount of boat/fishery/farming activities-related litter was as high as $19.4 \%$ at Volano; it was similar at Bellocchio (18.7\%), and lower at the other beaches (e.g. Rosolina, $11 \%$ ). Similar values were found by Thiel et al. (2013) on beaches of central Chile, by Claereboudt (2004) on beaches of the Gulf of Oman, and by Edyvane et al. (2004) on beaches of the Great Australian Bight (South Australia). Litter originating from fishery/farming behavior often reaches very high proportions ( $>50 \%$ ) of all marine litter in remote areas, where contributions from other sources are small (Convey et al., 2002). For example, Whiting (1998) found that commercial fishing, merchant shipping and recreational boaters contributed over $85 \%$ of all litter found on uninhabited islands in Northern Australia. While at Volano and Bellocchio the contribution of fishing and aquaculture litter was high due to the proximity of clam and mussel farms, it was substantially surpassed by that of shoreline and recreational activities-related litter.

Litter originating from dumping activities also contributed substantially (this study: 18.9\%; Mediterranean average: $2 \%$; PNUE/PAM/MEDPOL, 2009). The number of large (e.g. Adige and Po) and smaller (e.g. Reno, Lamone, Fiumi Uniti and Bevano) rivers that flow into this coastal area can transport litter from inland sources to the coast thereby contributing to densities of litter on the beaches. The input of litter by rivers can be intensified by rain (Shimizu et al., 2008), and, in north-eastern Italy, winter 2014-2015 was among the wettest in decades (www.meteoromagna.com). As a matter of fact, Volano (which is the nearest beach to the Po deltaic branches) and Rosolina (which is delimited by the Adige at north) exhibited the highest density of dumping activities-related litter. However, the fact that the density of that litter was lower than in other localities (e.g. Jayasiri et al., 2013; Langlbauer et al., 2014), may indicate that here the collection and disposal of municipal litter is more efficient than elsewhere.

\section{Conclusions}

The present study provides the first assessment of marine litter pollution in 5 beaches along the north-western Adriatic coast, and it constitutes a starting point for the reaching of GES for this coastal area. Results from this study strongly indicates that most marine litter in the 5 beaches comes from very local sources. Our results also suggest that a high proportion of litter on the 5 beaches has been directly deposited there by beach users. Our findings may provide insights into possible approaches to manage marine litter deposition on Adriatic free access beaches. The high proportion of litter that was deposited in situ suggests mitigation actions that may substantially help to address the problem: (i) to promote the concept of "Leave No Trace" to beach users; (ii) to develop an approach of direct intervention through signage and patrols; (iii) to increase targeted clean up, particularly in summer months when the number of tourists is maximum; (iv) to implement actions aimed at raising awareness of audiences which may (unknowingly) be contributing to the marine litter issue; (v) to foster broader education and awareness to shellfish farmers in relation to marine litter.

\section{Acknowledgements}

We thank four anonymous reviewers whose constructive criticism greatly improved the quality of this manuscript.

\section{References}

Abu-Hilal, A.H., Al-Najjar, T., 2004. Litter pollution on the Jordanian shores of the Gulf of Aqaba (Red Sea). Mar. Environ. Res. 58, 39-63.

Alkalay, R., Pasternak, G., Zask, A., 2007. Clean-coast index: a new approach for beach cleanliness assessment. Ocean Coast. Manage. 50, 352-362.

Anderson, M.J., Robinson, J., 2003. Generalised discriminant analysis based on distances. Aust. NZ J. Stat. 45, 301-318.

Anderson, M.J., Gorley, R.N., Clarke, K.R., 2008. PERMANOVA+ for PRIMER: Guide to Software and Statistical methods. PRIMER-E Ltd., Plymouth, UK.

Angiolillo, M., di Lorenzo, B., Farcomeni, A., Bo, M., Bavestrello, G., Santangelo, G. Cau, A., Mastascusa, V., Cau, A., Sacco, F., Canese, S., 2015. Distribution and assessment of marine debris in the deep Tyrrhenian Sea (NW Mediterranean Sea, Italy). Mar. Pollut. Bull. 92, 149-159. 
Araújo, M.C.B., Santos, P.J.P., Costa, M.F., 2006. Ideal width of transects for monitoring source-related categories of plastics on beaches. Mar. Pollut. Bull. $52,957-961$.

Benton, T.G., 1995. From castaways to throwaways: marine litter in the Pitcairn Islands. Biol. J. Linnean Soc. 56, 415-422.

Borja, A., Elliott, M., Carstensen, J., Heiskanen, A.-S., van de Bund, W., 2010. Marine management - towards an integrated implementation of the European Marine Strategy Framework and the Water Framework Directives. Mar. Pollut. Bull. 60, 2175-2186.

Cheshire, A.C., Adler, E., Barbière, J., Cohen, Y., Evans, S., Jarayabhand, S., Jeftic, L., Jung, R.T., Kinsey, S., Kusui, E.T., Lavine, I., Manyara, P., Oosterbaan, L., Pereira, M. A., Sheavly, S., Tkalin, A., Varadarajan, S., Wenneker, B., Westphalen, G., 2009. UNEP/IOC Guidelines on Survey and Monitoring of Marine Litter. UNEP Regional Seas Reports and Studies, No. 186; IOC Technical Series No. 83, xii + 120 p.

Claereboudt, M.R., 2004. Shore litter along sandy beaches of the Gulf of Oman. Mar. Pollut. Bull. 49, 770-777.

Clarke, K.R., 1993. Non-parametric multivariate analyses of changes in community structure. Austral. J. Ecol. 18, 117-143.

Convey, P., Barnes, D., Morton, A., 2002. Debris accumulation on oceanic island shores of the Scotia Arc, Antarctica. Polar Biol. 25, 612-617.

Cunningham, D.J., Wilson, S.P., 2003. Marine debris on beaches of the greater Sydney Region. J. Coast. Res. 19, 421-430.

Derraik, J.G.B., 2002. The pollution of the marine environment by plastic debris: a review. Mar. Pollut. Bull. 44, 842-852.

Edyvane, K.S., Dalgetty, A., Hone, P.W., Higham, J.S., Wace, N.M., 2004. Long-term marine litter monitoring in the remote Great Australian Bight, South Australia. Mar. Pollut. Bull. 48, 1060-1075.

European Commission, 2008. Directive 2008/56/EC of the European Parliament and of the Council of 17 June 2008, establishing a framework for community action in the field of marine environmental policy (Marine Strategy Framework Directive).

Evans, S.M., Dawson, M., Day, J., Frid, C.L.J., Gill, M.E., Pattisina, L.A., Porter, J., 1995. Domestic waste and TBT pollution in coastal areas of Ambon Island (Eastern Indonesia). Mar. Pollut. Bull. 30, 109-115.

Foster-Smith, J., Birchenough, A.C., Evans, S.M., Prince, J., 2007. Human impacts on Cable Beach, Broome (Western Australia). Coast. Manage. 35, 181-194.

Garrity, S.D., Levings, S.C., 1993. Marine debris along the Caribbean coast of Panama. Mar. Pollut. Bull. 26, 317-324.

Gregory, M.R., 2009. Environmental implications of plastic debris in marine settings - entanglement, ingestion, smothering, hangers-on, hitch-hiking and alien invasions. Phil. Trans. Royal Soc. B 364, 2013-2025.

Hinojosa, I.A., Thiel, M., 2009. Floating marine debris in fjords, gulfs and channels of Southern Chile. Mar. Pollut. Bull. 58, 341-350.

Jayasiri, H.B., Purushothaman, C.S., Vennila, A., 2013. Quantitative analysis of plastic debris on recreational beaches in Mumbai, India. Mar. Pollut. Bull. 77, 107-112.

Kuo, F.-J., Huang, H.-W., 2014. Strategy for mitigation of marine debris: Analysis of sources and composition of marine debris in northern Taiwan. Mar. Pollut. Bull. $83,70-78$.
Kusui, T., Noda, M., 2003. International survey on the distribution of stranded and buried litter on beaches along the Sea of Japan. Mar. Pollut. Bull. 47, 175-179.

Laglbauer, B.J.L., Melo Franco-Santos, R., Andreu-Cazenave, M., Brunelli, L. Papadatou, M., Palatinus, A., Grego, M., Deprez, T., 2014. Macrodebris and microplastics from beaches in Slovenia. Mar. Pollut. Bull. 89, 356-366.

Lee, J., Hong, S., Song, Y.K., Hong, S.H., Jang, Y.C., Jang, M., Shim, W.J., 2013. Relationships among the abundances of plastic debris in different size classes on beaches in South Korea. Mar. Pollut. Bull. 77, 349-354.

Liu, T.-K., Wang, M.-W., Chen, P., 2013. Influence of waste management policy on the characteristics of beach litter in Kaohsiung, Taiwan. Mar. Pollut. Bull. 72, 99-106.

Lopes da Silva, M., Vieira de Araújo, F., Oliveira Castro, R., Souza Sales, A., 2015 Spatial-temporal analysis of marine debris on beaches of Niterói, RJ, Brazil: Itaipu and Itacoatiara. Mar. Pollut. Bull. 92, 233-236.

Ocean Conservacy, 2010. A rising tide of ocean debries. 2009 Report. Washington DC, USA, 64 p.

Oigman-Pszczol, S.S., Creed, J.C., 2007. Quantification and classification of marine litter on beaches along Armacao dos Búzios, Rio de Janeiro, Brazil. J. Coast. Res. 23, 421-428.

PNUE/PAM/MEDPOL, 2009. Results of the assessment of the status of marine litter in the Mediterranean. Meeting of MED POL Focal Points No. 334, 91 p.

Poeta, G., Battisti, C., Acosta, A.T.R., 2014. Marine litter in Mediterranean sandy littorals: Spatial distribution patterns along central Italy coastal dunes. Mar. Pollut. Bull. 89, 168-173.

Shimizu, T., Nakai, J., Nakajima, K., Kozai, N., Takahashi, G., Matsumoto, M., Kikui, J., 2008. Seasonal variations in coastal debris on Awaji Island, Japan. Mar. Pollut. Bull. 57, 182-186.

Slavin, C., Grage, A., Campbell, M.L., 2012. Linking social drivers of marine debris with actual marine debris on beaches. Mar. Pollut. Bull. 64, 1580-1588.

Smith, S.D.A., Markic, A., 2013. Estimates of marine debris accumulation on beaches are strongly affected by the temporal scale of sampling. PLoS ONE 8, e83694.

Strafella, P., Fabi, G., Spagnolo, A., Grati, F., Polidori, P., Punzo, E., Fortibuoni, T. Marceta, B., Raicevich, S., Cvitkovic, I., Despalatovic, M., Scarcella, G., 2015. Spatial pattern and weight of seabed marine litter in the northern and central Adriatic Sea. Mar. Pollut. Bull. 91, 120-127.

Thompson, R.C., 2006. Plastic debris in the marine environment: consequences and solutions. In: Krause, J.C., Nordheim, H., Bräger, S. (Eds.), Marine Nature Conservation in Europe. Federal Agency for Nature Conservation, Stralsund, Germany, $107-115$ pp.

UNEP, 2009. Marine litter: A global challenge. Nairobi: UNEP, 232 p.

Velander, K.A., Mocogni, M., 1999. Beach litter sampling strategies: is there a 'best' method? Mar. Pollut. Bull. 38, 1134-1140.

Walker, T.R., Reid, K., Arnould, J.P.Y., Croxall, J.P., 1997. Marine debris surveys at Bird Island, South Georgia 1990-1995. Mar. Pollut. Bull. 34, 61-65.

Whiting, D., 1998. Types and sources of marine debris in Fog Bay, Northern Australia. Mar. Pollut. Bull. 36, 904-910.

Widmer, W.M., Hennemann, M.C., 2010. Marine debris in the Island of Santa Catarina, South Brazil: spatial patterns, composition, and biological aspects. J. Coast. Res. 26, 993-1000. 